\title{
CHIEF JUSTICE ATTACKS INACCESSIBILITY \\ OF LAW IN AUSTRALIA
}

Governments do not seem to experience any difficulty in making laws. The number of codes, statutes, decrees, orders, regulations, rules, and other legislative instruments throughout the world is rising astronomically, and there can be no doubt anymore that the 20th century will go down in history as the age of lawmaking. Wherever we may live-north, or south, east or west-we find that mankind is overlegislated and overregulated.

One might at least expect that intensive lawmaking would be accompanied by an efficient legal publication system. After all, printing technology has reached the heights of sophistication and the transmission of information can now proceed from one end of the globe to the other within the fraction of a second. Alas, governments may have learned to regulate, but they have not yet managed to devise a system whereby the public can have a relatively simple and easy access to the rules and regulations that it is expected to obey.

From time to time a sympathetic judge or official, exasperated by this sorry state of affairs, will speak out for its improvement. To law librarians, as the foregatherers of legal information, such statements are like honey on bread. It is for this reason that law library publications, such as this one, assiduously record judicial comments on the subject lest they be lost to posterity.

With the good offices of the Australian Law Librarians' Group Newsletter (October 1979) we bring to our readers' attention an excerpt from an opinion of Sir Garfield Barwick, the Chief Justice of the High Court of Australia, which contains the most recent known criticism of government for its inefficiency in law publishing:

"From the statements made to the Court from time to time, on occations by representatives of the Crown, it is apparent that there has been neglect on the part of government in providing adequate copies of regulations for purchase by the public. It should be borne in mind that not only should they be capable of purchase at the time they are notified or by the time they are said to operate but they ought to be available to the citizen subsequently if an occasion arises for him to know with precision what exactly they provide. Too often, one hears the statement that the regulations are 'out of stock'. This, in my opinion, is an unbearable and a completely unacceptable situation. There can be no impediment whatever to government ensuring that stocks are maintained of all regulations available to be procured by the citizen on demand. It may be a manifestation of the laxity that does enter into the making of law by regulation: it seems to me, therefore, that it is essential that officialdom ensure that copies of regulations are available at the place nominated in the gazette, and that thereafter an appropriate stock of them is maintained. Of course, if available at the earlier time, subsequent failure to maintain stocks will not affect the operation of the regulation. 
There should be no difficulty, having regard to the resources of government, in having copies of the regulations available at the notified place or places at the time of notification in the gazette or at any subsequent date on which they are to become operative.

I regard the availability of the terms of the law to the citizen of paramount importance. No inconvenience in government administration can, in my opinion, be allowed to displace adherence to the principle that a citizen should not be bound by a law the terms of which he has no means of knowing. Thus, in my opinion, if it is proved that copies of the regulations were not available for purchase at the place specified, the regulations would not have commenced to operate".

[For the full opinion, see Watson \& Anor. v. Lee \& Anor., October 23, 1979. Citation not available at the time of this writing.]

\section{PRIVACY LAW IN AUSTRALIA}

In conjunction with its inquiry into the law of defamation, the Law Reform Commission of Australia has also examined infringements of privacy by what it terms "Unfair Publication", e.g., appropriation of a person's name, identity or likeness for the sole advantage of the publisher. The Commission has touched upon a novel concept of law in which it has attempted to balance the competing interests of individual honor, reputation and dignity with the public rights of freedom of expression and access to information.

Findings of the Commission appear in its report No. 11 entitled "Unfair Publication: Defamation and Privacy". The report is about 290 pages long. Published by the Australian Government Publishing Service, it is priced at $\mathrm{A} \$ 6.85$. Its catalog number is 7874713 .

\section{PERIODICALS SURVEY}

The Winter 1980 issue of the Computer/Law Journal (Vol. II, No. 1) is entirely devoted to a survey of electronic fund transfers in banking and other financial operations. Centering on the recent United States Electronic Fund Transfer Act, the collection of articles nevertheless reaches out beyond mere interpretative considerations of this statute. Several articles describe clearly, and yet in great detail, how electronic fund transfers operate, what are the advantages of electronic giro payments (which, without the aid of electronics, have been widely used in many European countries for a long time), and what are some of the practical implications of changing from a conventional check (cheque) payment 